\title{
REFERENCES
}

Balchin, W. G. V., 1952. The Erosion Surfaces of Exmoor and Adjacent Areas. Geogr. J., 118, 453-476.

Dewey, H., 1910. Notes on some Igneous Rocks from North Devon. Proc. Geol. Ass., Lond., 21, 429-434.

Maw, G., 1864. On a Supposed Deposit of Boulder-Clay in North Devon. Quart. J. geol. Soc. Lond., 20, 445-451.

TAYLOR, C. W., 1956. Erratics of the Saunton and Fremington Areas. Rep. Devon. Ass. Adv. Sci., 88, 52-64.

1958. Some Supplementary Notes on Saunton Erratics. Ibid., 90, 187-191.

VAchell, E. T., 1963. 5th Report on Geology. Rep. Devon. Ass. Adv. Sci., $95,100-7$.

Zeuner, F. E., 1959. The Pleistocene Period. London.

Muriel A. Arber.

18 Sherlock Close,

CAMBRIDGE.

8th March, 1964.

\section{NEW LIGHT ON THE DAWROS PERIDOTITE}

SIR,-Dr. Leake in a recent paper (Geol. Mag., 101, 63-75) presents some new ideas on the peridotite intrusion at Dawros in Connemara (Ingold, 1937; Rothstein, 1957).

Evidence is given by Dr. Leake for a transition from the non-feldspathic ultramafic rocks to the gabbro found associated with the intrusion; and new points are raised on the possible folded character of the main body of the peridotite.

In 1957 I drew attention to what I considered to be the intrusive character of the junction between the peridotites and the gabbro. In my thesis (1954), also referred to by Dr. Leake, some details of this boundary were given, including its abrupt nature and the absence of plagioclase in the immediately adjacent peridotites. Also described in the thesis was the presence of plagioclase in the gabbro. If evidence for a transition between these two groups of rocks has been found then this adds to the interest of the Dawros intrusion. However, I am not convinced that the peridotite layer in the gabbro as shown by Leake (1964, Plate II, fig. 2) is a true layer of primary igneous accumulation. It may be a raft from the layered ultramafic caught up in the gabbro. Until this point is decided the significance of the mineral assemblages in it must remain indeterminate. Likewise, how does the petrography of this "layer" compare with that of the rare rocks, within the peridotite itself, newly recorded by Leake $(1964$, p. 65$)$ as containing feldspar? The statement concerning the mineral assemblages present requires further petrographic details.

The detailed study I undertook of the phase petrology of the non-feldspathic ultramafic rocks of the Dawros intrusion was developed by means of a comparison with that of the feldspathic peridotites of the Belhelvie intrusion in Aberdeenshire (Stewart, 1947), and by taking into account a variety of published experimental and theoretical data (given in full in the bibliography of Rothstein, 1962a). This study brought to notice a number of interesting points (Rothstein, 1961 $a, 1961 b, 1962 a, 1963)$. Some of these include the relations between spinel and plagioclase. A variety of possibilities were shown to exist including some of those now put forward by Leake $(1964$, p. 73 , et seq.), for example, the role of $\mathrm{Cr}_{2} \mathrm{O}_{3}$. It is not possible, however, to choose between these different possibilities on the basis of the amount of new evidence published so far. More curious in my opinion, from the point of view of the phase petrology of the Dawros intrusion, is the status of the hypersthene-bearing pyroxenites with their highly aluminous pyroxenes 
(Rothstein, 1957, p. 9 ; 1958, p. 458; 1962a, p. 23, et seq.). I do not think that these particular rocks can be placed in a straightforward manner into the igneous sequence at Dawros as Dr. Leake suggests (Leake, 1964, p. 65).

Two hypotheses are put forward by Dr. Leake concerning the possible folding of the intrusion (Leake, 1964, p. 71). Both of these are of interest. The first, however, which regards the "thick chromite layer" as part of "the bottom of the intrusion", implicitly denies the possibility of taking into account the systematic variation in the mineral assemblages of the ultramafic rocks. In particular it avoids the evidence related to the passage of the chrome-spinel horizon from the western unrecrystallized part of the Dawros intrusion to its eastern recrystallized portion [and it may be noted here that the spinel analyses referred to by Leake $(1964$, p. 73$)$ are not ones from this horizon]. The second hypothesis of folding takes into account the considerable detail of the phase assemblages of the primary mineral layering already published (Rothstein, 1957), but since this makes the folding more complex it is considered as uncertain. This on the basis of "a few scattered observations " (Leake, 1964, p. 73). I might add here that the investigation of the primary and secondary phase assemblages of this intrusion is still proceeding and in the future new mineral analyses from these rocks will be published.

In the bibliography Dr. Leake refers to the translated version of my paper on the phase relations in the Dawros and Belhelvie intrusions (Rothstein, $1961 \mathrm{~b}$ ). This contains so many errors in its translation into English that it is virtually incomprehensible. It can only be understood when the list of corrections subsequently published for the translators is taken into account (Rothstein, 1962b).

The Dawros intrusion may well be folded in a manner similar to that proposed by Dr. Leake. It would be most encouraging if the abundance of detail revealed by its systematic mapping as a layered body, as originally suggested by Professor Wager, could help to unravel further details of the complexities brought to light in the course of a detailed structural survey. Indeed it might be possible, by taking into account the structure of the whole surrounding area, to show the relations between the variety of rocks found within the Dawros intrusion and those isolated outcrops of petrographically similar ultramafic rocks which occur in the vicinity of the CurrywongaunDoughruagh gabbroic intrusions to the east.

\section{REFERENCES}

INGoLD, L. M., 1937. The Geology of the Currywongaun-Doughruagh area, Co. Galway. Proc. roy. Irish Acad., B, 43, 135-159.

Leake, B. E., 1964. New Light on the Dawros Peridotite, Connemara, Ireland. Geol. Mag., 101, 63-75.

Rothstein, A. T. V., 1954. Studies in the Serpentine Rocks. D.Phil. thesis, Oxford.

1957. The Dawros Peridotite, Connemara, Eire, Quart. Jour. geol. Soc. Lond., 113, 1-25.

1958. Pyroxenes from the Dawros Peridotite. Geol. Mag., 95, 456-462.

1961a. A synorogenic peridotite at Dawros, Connemara. Acta Geologica, 7, $221-232$.

$1961 b$. Phase relations in the peridotites of Dawros (Eire) and Belhelvie (Scotland). (In Russian) Izvest. Akad. Nauk SSSR. Ser. Geol., 3, 69-86.

1962a. Magmatic Facies in ultrabasic igneous rocks of the Tholeitic series. (In Russian with English summary.) Publishing House of the U.S.S.R. Academy of Sciences.

$1962 b$. Corrections to the English translation of $1961 b$ above. Izvest. Akad. Nauk SSSR. Ser. Geol., 12, p. 122. (American Geological Institute.) 
Rothstein, A. T. V., 1963. Remarks in discussion on paper by D. R. Bowes and R. G. Park. Proc. geol. Soc. Lond., 1608, 85-6.

Stewart, F. H., 1947. The Gabbroic Complex of Belhelvie in Aberdeenshire. Quart. Jour. geol. Soc. Lond., 102, 465-498.

DEPARTMENT OF BIOLOGY AND GEOLOGY,

A. T. V. RothstenN.

NorwoOd TeCHNICAL COLlege,

KNIGHTS HiLl,

LoNDON, S.E. 27.

15th March, 1964.

\section{TONSTEIN BAND IN THE SOUTH LANCASHIRE COALFIELD}

SiRS,- R. A. Eden et al. ${ }^{1}$ refer to the discovery of several tonstein bands in the coalfields of the East Midlands. In May 1961, a 1 inch tonstein band was discovered in the upper part of the Worsley Four Feet Seam at Agecroft Colliery, Lancashire, in the course of work on the petrology of coal seams and associated measures, at the Chester Coal Survey Laboratory (now operating from Shade House, Pendlebury).

Macroscopically, the band had been recorded as an inferior dull coal. However, on microscopical examination, with oil immersion objectives, of stained polished blocks, vermicules of kaolinite, displaying the characteristic "cat's tail "structure, were clearly visible. A considerable amount of carbonaceous matter was also present, the ash content of the band being 46 per cent.

Thin sections were prepared at the Sheffield Coal Survey Laboratory and it was confirmed that the band was indeed a tonstein, containing lenses of microcrystalline kaolinite in addition to the vermicules.

Examination of crushed samples of the seam from the nearby Astley Green Colliery also indicated the presence of the band at the same horizon. This band may be the equivalent of that recorded in the High Main Seam of the East Midlands.

Central, laboratory,

H. Mayland.

NORTH WESTERN Division,

National Coal. BoARd

PENDIEBURY, LANCS.

April, 1964.

1 Eden, R. A., R. W. Elliott, R. E. Elliott, and B. R. Young, Tonstein Bands in the Coalfields of the East Midlands. Geol. Mag., 1963, 100, 47-58.

\section{THECOSMILIA KAMBENSIS NOM. NOV. FOR T. MAGNA GREGORY SP. NON ÉTALLON}

SiR,-J. W. Gregory described a coral from the Kambe Limestone of Kenya as Aplophyllia magna (Monog. geol. Dept. Hunter. Mus., 4, (10), 1930, p. 204, pl. 19, figs. 3a, b), which in 1963 (Overseas Geol. Min. Resources, 9, (1), p. 36, pl. 3, fig. 4) I showed should be referred to Thecosmilia Edwards and Haime. I am indebted to Prof. O. F. Geyer, of Stuttgart, for pointing out to me that T. magna (Gregory) is thus a junior homonym of Thecosmilia magna Etallon (in Thurmann, J. and Etallon, A., Leth. bruntr., 1864, p. 385, pl. 54, fig. 11 ; see also Koby, F., Monographie des polypiers jurassiques de la Suisse, Mém. Soc. paléont. Suisse, 11, (4), 1884, p. 166, pl. 44, figs. 1-3, and Geyer, O. F., Paläont. Zeitsch., 29, (3/4), 1955, p. 119). I therefore propose the name Thecosmilia kambensis for T. magna Gregory sp. non Etallon. 